\title{
The Use of Mother Tongue in Foreign Language Teaching
}

\author{
Haining Xu \\ Faculty of Humanities and Foreign Languages of Xi'an University of Technology, Shaanxi, P. R. \\ China \\ xuhaining36@163.com
}

Keywords: mother tongue, Foreign Language Teaching, aspects

\begin{abstract}
The role of mother tongue has always been an important issue in the study of Foreign Language Teaching. In different methods and approaches, the role of mother tongue is different. Some researchers think that mother tongue is very important and should be used in Foreign Language Teaching; while, other researchers hold that mother tongue should be avoided in teaching foreign languages. Through methods of interview and questionnaires, the present study explores the use of mother tongue in College English classrooms: whether Chinese could be used in College English classrooms and if it could be used, then, in which aspects could Chinese be used. The results show that mother tongue could be used in College English classrooms and could be used to some extent when explaining new words, explaining grammar, and explaining text.
\end{abstract}

\section{Introduction}

The role of mother tongue has always been an important issue in the study of Foreign Language Teaching. Up to now, various methods and approaches have been used in English Language Teaching, such as the Grammar-Translation Method, the Oral Approach, the Audiolingual Method, Communicative Language Teaching, Community Language Learning, and the Natural Approach. Some methods and approaches lay great emphasis on listening and speaking; some stress the importance of reading and writing; and some others emphasize the comprehensive development of listening, speaking, reading, writing and translating. Therefore, the role of mother tongue is different in different methods and approaches.

\section{Literature review}

For some researchers, mother tongue is very important and should be used in Foreign Language Teaching. The Grammar-Translation Method, which dominated European and foreign language teaching from the 1840s to the 1940s, and continues to be widely used in modified form in some parts of the world today, holds that the student's native language is the medium of instruction. It is used to explain new items and to enable comparisons to be made between the foreign language and the student's native language. The reformers of the late $19^{\text {th }}$ century believed that translation should be avoided, but the mother tongue could be used in order to explain new words or to check comprehension. In Community Language Learning, mother tongue is used to provide the learning content. According to Communicative Language Teaching, judicious use of native language is accepted where feasible. Harbord (1992) pointed out that using mother tongue in foreign language classroom can provide learners of different levels with relatively equal learning opportunities[1].

However, other researchers hold that mother tongue should be avoided in teaching foreign languages. According to the Direct Method, classroom instruction should be conducted exclusively in the target language. Concrete vocabulary was taught through demonstration, objects, and pictures; abstract vocabulary was taught by association of ideas. In the Oral Approach, the target language is the language of the classroom. And the use of the student's native language is forbidden in the Audiolingual Method. George (1972) pointed out that using mother tongue may make the students form the habit of substitutability, which can cause interference in foreign language learning[2]. 
Perdue (1993), from a cognitive perspective, thought that the use of mother tongue may distract the students' attention and obstruct the restructuring of foreign language[3].

Bao (1998) observed the English classrooms of two secondary school classes and found that the teachers used mother tongue for the most of the time in the class[4]. The reason was that students liked this and mother tongue could help them understand the content better. Schweers (1999) conducted a survey on the use of mother tongue and found that most students and teachers approve the use of mother tongue in foreign language teaching[5]. Tang (2000) studied the use of mother tongue in College English classrooms and found that mother tongue is commonly used. Moreover, teachers and students held positive attitude towards the use of mother tongue[6]. Wang \& Wen (2002) studied students' use of mother tongue in writing process. They found that mother tongue is a very important psychological tool in students' writing process, helping them to scaffold language and to externalize their inner speech in some difficult cognitive activities[7].

In various researches, it has been reported that mother tongue is used for different purposes in EFL or ESL classes, such as explaining the grammar, giving instructions, helping students, checking students, or correcting the activities [8, 9]. In addition, using L1 helps maintain class discipline, build rapport and reduce social distance with students [10, 11]. Paker \& Karaagac (2015) studied and analyzed the use and functions of mother tongue in EFL classed in Turkey. Their data have revealed that mother tongue is an inseparable part of language teaching, and it actually has different functions like "rapport building purposes", "making the topic/meaning clear (by giving examples, explaining, making extra explanations, etc.)", "explaining difficult concepts or ideas", etc. They also found out that both the instructors and the students could not deny the need of mother tongue from time to time[12].

The purpose of the present study is to examine the use of mother tongue in Foreign Language Teaching, particularly in College English classrooms. This research paper is in an attempt to address the following two questions:

1) Could Chinese be used in College English classrooms?

2) If Chinese could be used in College English classrooms, then, in which aspects could Chinese be used?

\section{Research methodology}

\subsection{Participants}

The participants were 15 English teachers and 200 undergraduates from Xi'an University of Technology. The teaching experiences of the 15 teachers are ranging from 3 to 15 years. The 200 students are non-English majors chosen randomly and are specializing in Electrical Engineering, Computer Science, Civil Engineering, Material Science and Engineering, Business Administration, Finance and International Trade.

\subsection{Methods}

The methods used in this study were interview and questionnaires. The 15 teachers were interviewed in a casual way, by asking each of them three questions: (1) Do you use Chinese in English classroom? (2)Do you think using Chinese in English classroom can help the students' learning of English? (3) When will you use Chinese in English classroom?

The 200 students answered questions regarding the use of Chinese in English classrooms. There were 8 multiple choice questions in the questionnaire. The first 6 questions are about the students' overall attitude toward the use of Chinese in English classrooms; and the students should choose one from the 4 choices given. The last two questions are about the specific aspects in which Chinese could be used in English classrooms; and the students could choose more than one from the given 6 choices and could write down some others if it was not listed.

The questionnaire was constructed in English and translated into Chinese. 


\subsection{Data collection}

The 15 teachers were asked the three questions respectively. Their answers to the three questions were noted down during the interview. The questionnaires were randomly distributed to 200 freshmen in seven classes. The students were given one hour to finish the questionnaires. The 200 retrieved questionnaires were all valid. The rate of validity is 100 percent.

\section{Results and discussion}

\subsection{Results of the interview}

Each of the 15 teachers answered the three questions listed above. Table 1 shows teachers' responses to the use of Chinese in English classrooms.

Table 1. Teachers' responses to the use of Chinese in English classrooms

\begin{tabular}{cl}
\hline Questions & \multicolumn{1}{c}{ Answers (Frequency) } \\
\hline 1 & Seldom(1); Sometimes $(10) ;$ Often(4) \\
\hline 2 & Some help(14); Great help(1) \\
\hline (3) & $\begin{array}{l}\text { Explaining new words(6); Explaining grammar(14); } \\
\text { Explaining text(4); Doing exercises(5) }\end{array}$ \\
\hline
\end{tabular}

Notes: (1) Do you use Chinese in English classrooms?

(2) Do you think using Chinese in English classrooms can help the students' learning of English?

(3) When will you use Chinese in English classrooms?

From Table 1, we can see that almost all the teachers use Chinese in English classrooms. But 10 of them only use Chinese sometimes. And all the teachers think that using Chinese in English classrooms can help the students' learning of English. 14 of the 15 teachers think that there is some help, but not great help. For the third question, 14 of the 15 teachers use Chinese when explaining grammar and some teachers also use Chinese when explaining new words, explaining text and doing exercises.

\subsection{Results of the questionnaire}

Table 2 shows students' overall attitude toward the use of Chinese in English classrooms.

Table 2. Students' overall attitude toward the use of Chinese in English classroom

\begin{tabular}{ccccc}
\hline Questions & $\begin{array}{c}\text { No./Never. } \\
\text { Frequency/ (\%) }\end{array}$ & $\begin{array}{c}\text { Seldom./Little. } \\
\text { Frequency/ (\%) }\end{array}$ & $\begin{array}{c}\text { Sometimes./Some. } \\
\text { Frequency/ (\%) }\end{array}$ & $\begin{array}{c}\text { Often./Great. } \\
\text { Frequency/ (\%) }\end{array}$ \\
\hline (1) & $0 / 0$ & $76 / 38$ & $104 / 52$ & $80 / 10$ \\
\hline 2 & $8 / 4$ & $16 / 8$ & $36 / 18$ & $140 / 70$ \\
\hline 3 & $12 / 6$ & $20 / 10$ & $88 / 44$ & $80 / 40$ \\
\hline$(4)$ & $8 / 4$ & $8 / 4$ & $120 / 60$ & $64 / 32$ \\
\hline 5 & $4 / 2$ & $4 / 2$ & $104 / 52$ & $88 / 44$ \\
\hline 6 & $4 / 2$ & $16 / 8$ & $96 / 48$ & $84 / 42$ \\
\hline
\end{tabular}

Notes: (1) Does your English teacher use Chinese in classroom?

(2) Do you approve teachers' use of Chinese in English classrooms?

(3) Do you like teachers' use of Chinese in English classrooms?

(4) Do you think teachers' use of Chinese in English classrooms can help you learn English?

(5) Do you think teachers' use of Chinese in English classrooms can help you understand better?

(6) Do you think teachers' use of Chinese in English classrooms can make you feel relaxed?

The statistics in Table 2 shows that almost all the teachers use Chinese inEnglish classrooms. But $52 \%$ of the students think that their teachers only sometimes use Chinese. This is in accordance with teachers' answers. One hundred and forty (70\%) students approve teachers' use of Chinese in English classrooms. Eighty-eight (44\%) of the students like teachers' use of Chinese in English classrooms and eighty $(40 \%)$ like this very much. Over half $(60 \%)$ of the students think teachers' use 
of Chinese in English classrooms has some help in their English learning and another 32\% think it has great help. For the $5^{\text {th }}$ question, one hundred and four (52\%) of the students think that teachers' use of Chinese has some help for them to understand better, and another eighty-eight (44\%) students think it has great help. For the $6^{\text {th }}$ question, ninety-six (48\%) of the students think teachers' use of Chinese can sometimes make them feel relaxed, and another eighty-four (42\%) students think it can often make them feel relaxed.

From these statistics, we can see that students have positive attitudes toward the use of Chinese in English classrooms. About 85\% of the students approve and like teachers' use of Chinese in English classrooms. And over 90\% of the students think that teachers' use of Chinese in English classrooms can help them learn English, understand better, and can make them relaxed. So, maybe we can say that, to some extent, Chinese could be used in College English classrooms.

Table 3 shows students' responses to the specific aspects in which Chinese could be used in English classrooms.

Table 3. Students' responses to the specific aspects Chinese could be used

\begin{tabular}{cccccccc}
\hline Questions & $\underline{\mathrm{A}}$ & $\underline{\mathrm{B}}$ & $\underline{\mathrm{C}}$ & $\underline{\mathrm{D}}$ & $\underline{\mathrm{E}}$ & $\underline{\mathrm{F}}$ & $\underline{\mathrm{G}}$ \\
& F./ (\%) & F./ (\%) & F./ (\%) & F./ (\%) & F./ (\%) & F./ (\%) & F./ (\%) \\
\hline 7 & $104 / 52$ & $104 / 52$ & $92 / 46$ & $40 / 20$ & $16 / 8$ & $40 / 20$ & $12 / 6$ \\
\hline 8 & $112 / 56$ & $104 / 52$ & $112 / 56$ & $44 / 22$ & $16 / 8$ & $28 / 14$ & $12 / 6$ \\
\hline
\end{tabular}

Notes: i ) (7) When will your English teacher use Chinese in classrooms?

(8) In your opinion, when could your teacher use Chinese in English classrooms?

$\begin{array}{lll}\text { ii ) A. Explaining new words } & \text { B. Explaining grammar } \quad \text { C. Explaining text }\end{array}$

D. Doing exercises E. Asking Questions F. In-class discussion

G. Others

iii) F.= Frequency

The statistics in Table 3 shows that teachers most frequently use Chinese when explaining new words, explaining grammar, and explaining text and sometimes use Chinese when doing exercises and in-class discussion. From the answers to the $8^{\text {th }}$ question, we can see that over $50 \%$ of the students think teachers could use Chinese when explaining new words, explaining grammar, and explaining text and some think that teachers could use Chinese when doing exercises and in-class discussion.

From these statistics, we can see that teachers' use of Chinese in English classrooms is basically in accordance with students' expectation. Most of the students and teachers think that Chinese could be used when explaining new words, explaining grammar, and explaining text.

\section{Conclusion}

The role of mother tongue has always been an important issue in the study of Foreign Language Teaching. The results of this research indicate that Chinese is still extensively adopted in College English classrooms, and that both teachers and students respond positively to a reasonably use of the mother tongue. So, first, mother tongue could sometimes be used in College English classrooms because it helps students in their learning and understanding of English. Second, mother tongue could be used to some extent when explaining new words, explaining grammar, and explaining text. The role of mother tongue should be restricted to be facilitative, supportive and compensatory in foreign language classrooms. Both too much dependency and total prohibition of the mother tongue should be avoided.

There is one potential problem in this research. The participants are too limited. There are only 200 undergraduates and 15 teachers participated in this research and all of them are from the same university. Maybe, they are not quite representative. So, in the future research, more participants should be chosen and they' $d$ better be chosen from different universities. 


\section{Acknowledgement}

This research was financially supported by the Teaching Reform Funds of Xi'an University of Technology (Grant NO.Xjy0916).

\section{References}

[1] J. Harbord, The use of the mother tongue in the classroom, English Language Teaching Journal, vol.64, pp. 351-355, 1992.

[2] H. V. George, Common Errors in Language Learning, Rowley, Massachusetts: Newbury House Publishers, 1972.

[3] C. Perdue, Adult language acquisition: Cross-linguistic perspectives, Volume 1 Field Methods, Cambridge: Cambridge University Press, 1993.

[4] J. Bao, Problems of English teaching in secondary school, In K. Parry (ed.). Culture, Literacy and Learning English: Voices from the Chinese Classroom, Heinemann: Boynton/Cook publishers, pp.40-144, 1998.

[5] W. J. Schweers, Using L1 in the L2 classroom, Forum, vol.37, pp. 6-13, 1999.

[6] J. Tang, An empirical study of the use of the mother tongue in the L2 reading class, Hong Kong Journal of Applied Linguistics, vol.5, pp. 45-58, 2000.

[7] W. Wang and Q. Wen, L1 use in the L2 composing process: An exploratory study of 16 Chinese EFL writers, Journal of Second Language Writing, vol.11, pp. 225-246, 2002.

[8] S. Greggio and G. Gil, Teacher's and learners' use of code switching in the English as a foreign language classroom: a qualitative study, Linguagem \& Ensino, vol.10, pp. 371-393, 2007.

[9] M. E. Patel and P. M. Jain, English language teaching, Jaipur: Sunrise Publishers \& Distributors, 2008.

[10] F. Ramos, Spanish teachers' opinions about the use of Spanish in mainstream English classrooms before and after their first year in California, Bilingual Research Journal, vol. 29, pp. 411-433, 2005.

[11] L. Jingxia, Switching to L1 in the EFL classroom-the perspective of adaptation, The Open Applied Linguistics Journal, vol. 2, pp. 45-49, 2009.

[12] T. Paker and O. Karaagac, The use and functions of mother tongue in EFL classes, Social and Behavioral Sciences, vol. 199, pp.111-119, 2015. 